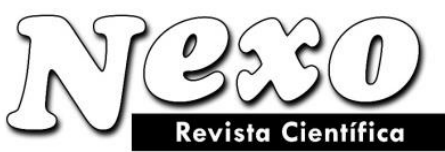

Vol. 34, No. 01, pp. 97-102/Marzo 2021

\title{
Bridge-type buildings on small rivers of cities as a solution to transport problems
}

\section{Edificios tipo puente en pequeños ríos de ciudades como solución a problemas de transporte}

\author{
Arkady V. Zakharov*, Tatiana R. Zabalueva \\ Moscow State University of Civil Engineering, Moscow, Russia. \\ zakharov.arkady@yandex.ru
}

(recibido/received: 03-January-2021; aceptado/accepted: 17-February-2021)

\begin{abstract}
The article deals with bridge-type buildings over small rivers of cities as an urban planning tool that facilitates transport problems in these cities. A large number of small rivers in cities, which create insurmountable obstacles for vehicles, separate urban districts preventing vehicles from moving from one district to another taking the shortest route. This circumstance forces vehicles to travel on major highways, overloading them and creating essential congestions. Embankments along small rivers also lead traffic flows to the main highways. As a result of the conducted research, the authors propose to create bridgetype buildings with transport turnpikes through these obstacles, using them for the infrastructure necessary for the city. Such bridge-type buildings can be constructed at the level of embankments, avoiding access trestles that significantly clutter up the adjacent streets and require reconstruction of the surrounding territories. Small bridge-type buildings for these purposes with a span of up to $25 \mathrm{~m}$ based on steelreinforced concrete structures are not expensive and can be financed by investors in case of their interest to rent premises located on the floors of such bridge-type buildings.
\end{abstract}

Keywords: bridge-type building, small rivers, motor transport, embankments, investors, steel-reinforced concrete floor structure.

\section{RESUMEN}

El artículo trata de las construcciones tipo puente sobre los pequeños ríos de las ciudades como herramienta de planificación urbana que facilita los problemas de transporte en estas ciudades. Una gran cantidad de pequeños ríos en las ciudades, que crean obstáculos insuperables para los vehículos, separan distritos urbanos impidiendo que los vehículos se muevan de un distrito a otro tomando la ruta más corta. Esta circunstancia obliga a los vehículos a transitar por las carreteras principales, sobrecargándolos y creando congestiones fundamentales. Los terraplenes a lo largo de los ríos pequeños también conducen a los flujos de tráfico hacia las carreteras principales. Como resultado de la investigación realizada, los autores proponen crear edificios tipo puente con autopistas de transporte a través de estos obstáculos, utilizándolos para la infraestructura necesaria para la ciudad. Tales edificios tipo puente pueden construirse a nivel de terraplenes, evitando los caballetes de acceso que abarrotan significativamente las 
calles adyacentes y requieren la reconstrucción de los territorios circundantes. Los pequeños edificios tipo puente para estos fines con una luz de hasta $25 \mathrm{~m}$ basados en estructuras de hormigón armado con acero no son costosos y pueden ser financiados por inversores en caso de que estén interesados en alquilar locales ubicados en los pisos de dichos edificios tipo puente.

Palabras clave: construcción tipo puente, pequeños ríos, transporte motorizado, terraplenes, inversores, estructura de piso de hormigón armado.

\section{INTRODUCTION}

Well-known transport problems in large cities and megacities concern not only residents of these areas but also specialists who can find solutions to these problems. At present, specialists in the construction of transport bridges and overpasses are mainly involved in solving the issues of congestion of city highways. However, with the high cost of these structures, their construction is given to government establishments that do not receive quick financial return on these structures. For many years, this problem is being considered by the authors representing the Moscow State University of Civil Engineering (MSUCE). It is proposed to solve the concerned problem using bridge-type buildings, which, on the one hand, are a transport artery with limited traffic of only passenger vehicles, and, on the other hand, include functions needed for the city (trade, storage facilities, parking lots, etc.). At that, all areas for placing these objects are given in use to the investor, which shares the financial costs with the state.

Bridge-type buildings can be built over any obstacles which break the urban structure into separate districts and cannot be overcome by vehicles. Such obstacles include man-made structures (railway tracks, major highways, industrial areas, etc.), as well as natural obstacles (ravines, streams, rivers, etc.). The present article discusses the possibility of constructing bridge-type buildings over small rivers in cities.

\section{BRIDGE-TYPE BUILDINGS AS AN EFFECTIVE WAY OF PUBLIC-PRIVATE PARTNERSHIP IN THE ROAD AND BRIDGE CONSTRUCTION}

Small rivers and streams appeared and existed in today's territories of cities long before their foundation, and performed various functions caused by the needs of citizens (drinking and technological water supply and sanitation, transport, recreation needs, etc.), i.e. were used for household and economic needs. In the territory of Moscow, for example, there are about a hundred rivers. As the demand for areas for building and the development of road networks grew, the smallest streams and rivers were directed to underground collectors, while larger ones were completed with transport and pedestrian embankments and river-bank park areas. In Moscow, the total length of land plots along rivers suitable for development is about 150 $\mathrm{km}$. These are the lands suited along the rivers Moscow, Yauza, Setun, Ochakovka, Ramenka, Skhodnya, Chermyanka, Likhoborka, Ponomarka, Kotlovka, Korshunikha, Chertanovka, Gorodnya, Newarka, Churilikha, etc. All open rivers, being long obstacles, whose total length in large cities reaches tens or hundreds of kilometers, break the urban road and street networks. Thus, the length of the Moscow River within the city is about $80 \mathrm{~km}$, while the length of small rivers is about $160 \mathrm{~km}$ (Kocheshkova, Zabalueva, 2009).

The problem of rupture of urban road networks has become particularly critical due to the rapid motorization of cities and a significant lag in the pace of construction of bridges (whose number can reach from several dozen to several hundred depending on the size of the city) connecting urban areas separated by rivers and streams (Vladimirov, 2014; Kuzmich, Fedina, 2008).

The lack of state funds for bridge and road construction forces to attract private investment with the subsequent implementation of tolls, which is not welcomed by road users. To effectively attract private capital in solving the transport problem, it is proposed to build facilities which along providing the transport function would bring a quick and significant income. Such objects can be bridge-type buildings, 
which, along with the roadway, should contain rental areas intended for placing the facilities for trade, high-income production, or areas for socially needed functions in the particular district. The desire to use bridge-type buildings for such purposes excites the minds of architects for a long time. For example, the BIG Bureau in Norway under the leadership of Bjarke Ingels proposed a bridge pavilion in Kistefos Park (Fig. 1) to host a Museum in it (Karpukhina, 2019). However, there is no roadway in this bridge-type building.

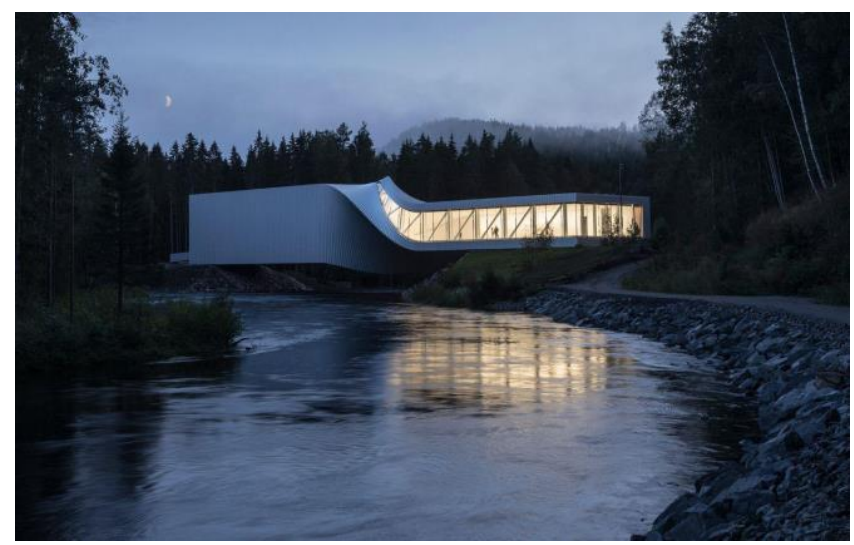

Figure 1. Pavilion bridge in the Kistefos Park, Norway

\section{ARCHITECTURAL, CONSTRUCTION, AND URBAN ADVANTAGES OF USING BRIDGE-TYPE BUILDINGS}

The project of a cultural and leisure bridge-type building over the Yauza River was proposed by Russian authors (Fig. 2). The structure includes a roadway, which is visible on the lower level of the building, highlighted in blue in the sectional drawing.

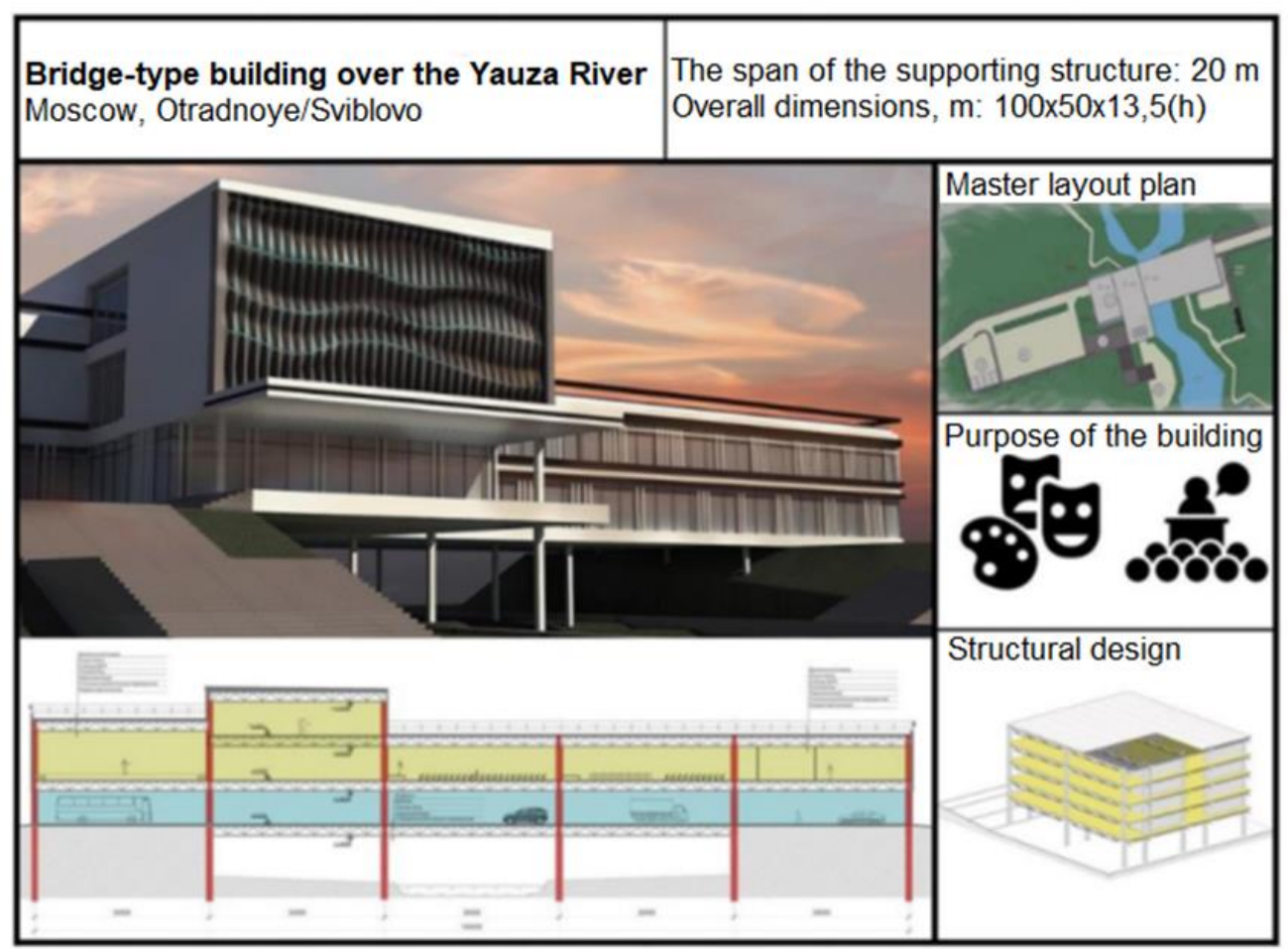

Figure 2. Project of a cultural and leisure bridge-type building over the Yauza River. Arkhitect Yu.S. Gribach 
The considered example of the Yauza River and adjacent buildings identified seven potential sites for the possible construction of bridge-type buildings to arrange exhibition halls, cultural centers and clubs, cinemas, multifunctional state service centers, dry cleaners, museums, gyms, coworking spaces, technology parks, saunas, bars and restaurants, photo services, and hotels. Thus, it can be noted that the range of functional content of such a building is quite wide (Lipadat, 2020).

The Chair of Architecture at the MSUCE develops design proposals for such bridge-type buildings, whose structural basis is a steel-reinforced concrete frame with a grid of supports of 20x10 m, unified for bridge spans and spans of building premises (Zabalueva, Zakharov, Maslova, 2014). This article discusses the most effective bridge-type buildings in which the level of the roadway coincides with the level of the road surface of adjacent streets. In this case, there is no need to build expensive access trestles cluttering up the space of adjacent streets.

The construction of bridge-type buildings over small rivers of cities at the level of the roadway is possible because these rivers are not navigable; they can be used just for small private vessels such as boats or small motorboats that do not require a large technological space above them (Zakharov, Fleishman, 2016).

While considering the Yauza River in Moscow as an example, one can note that its length within the city limits is 27.6 kilometers, and while considering the part of the river from the city center to the Moscow Automobile Ring Road (MKAD), its length is $9.8 \mathrm{~km}$. Analysis of existing crossings over the river shows that the distances to cross the river vary from $990 \mathrm{~m}$ to $1,730 \mathrm{~m}$ (Lipadat, 2020). And currently, these are mostly pedestrian crosswalks.

For the case of the Yauza River in Moscow taken as an example, along with other possibilities for constructing the bridge-type buildings based on the load-bearing floor structural system, the option of lowspan bridge-type buildings, whose span is no more than $25 \mathrm{~m}$ and the structural basis is a steel-reinforced concrete frame with a grid of supports 20x10 m, can be applied as well (Zakharov, Fleishman, 2016). The building is located at the level of riverfronts and does not require the access trestle (Fig. 3). Thus, automobile driveways are located on both sides of the building on adjacent embankments to make the bridge-type building design most compact. Along the embankments, traffic is carried out in one direction on each side, so the entrance to the roadway of the bridge-type building is carried out without crossing with the oncoming traffic. While automobile traffic in this transport hub is organized as comfortably as possible, the pedestrians experience some inconvenience when crossing with the traffic of vehicles, coming in and going out of the bridge.

The greatest efficiency of using small bridge-type buildings can be achieved when their traffic capacity and the type of transport passed through are consistent with the specified characteristics of the connected streets. The intersection of access trestles with streets in the same plane will allow minimal means (without overpasses) uniting the existing street and road network torn by small rivers, and, provided a sufficient number of bridge-type buildings, create more rational and calm traffic conditions for local vehicles, without the need to exit on highways. This will lead to a reduction in traffic jams on highways that will be freed of a large number of vehicles that run local routes, and will perform their main function of passing transit transport. 


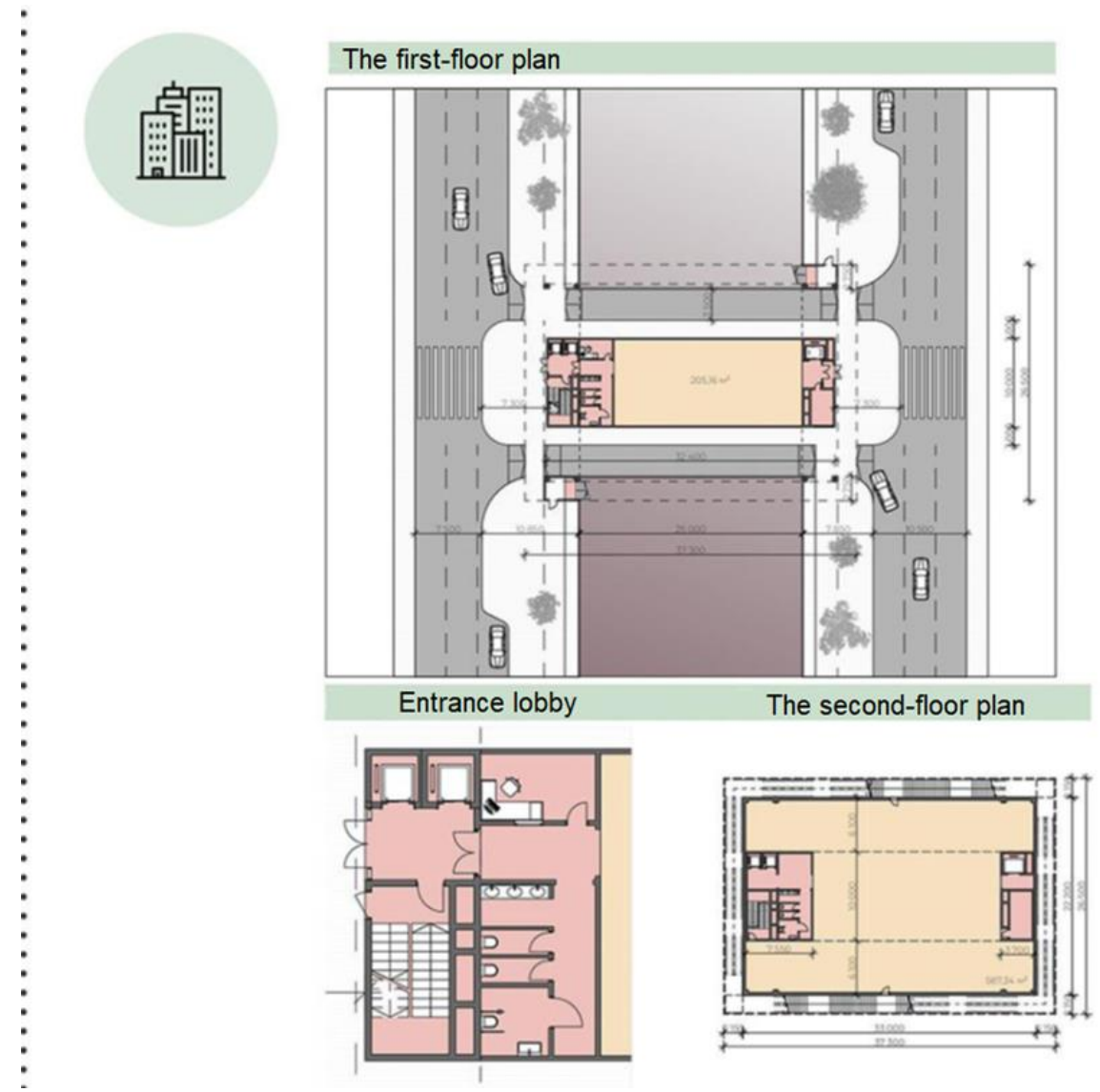

Figure 3. Diagram of a low-span bridge-type building at the level of adjacent riverfront. Architect V. Lipadat

Certain inconveniences that occur at the intersection of automobile and pedestrian traffics are not critical, since pedestrian traffic along the embankments is extremely small.

Thus, low-span bridge-type buildings over small rivers of cities address simultaneously two problems: on the one hand, solving the harsh problem of congestion of vehicles on highways, significantly unloading them from the excess of vehicles, and, on the other hand, the problem of financing such structures, including the interest of investors in using the areas of these structures based on full ownership, while freeing municipal authorities from investing in the construction of such buildings. At that, architectural and urban planning and design solutions for low-span bridge-type buildings built at the level of adjacent streets or embankments are the most cost-effective.

\section{CONCLUSION}

The construction of bridge-type buildings across small rivers in cities is not only possible but also one of the most effective means to solve the problems of traffic congestion, unloading major highways from those vehicles that will be able to take advantage of short passages through the bridge-type buildings. At the same time, the city will get additional functional areas to accommodate the necessary infrastructure. At that, part of the financing of such structures will be taken over by the investors interested in getting space for their own use, especially since there is a catastrophic lack of free lands for new construction in large cities and megacities. 


\section{REFERENCES}

Karpukhina, E. (2019). The first BIG project in Norway: The Museum and the pavilion bridge in Kistefos Park. Retrieved from https://www.admagazine.ru/architecture/pervyj-proekt-big-v-norvegii-muzejnyjpavilon-most-v-parke-kistefos

Kocheshkova, E.I., Zabalueva, T.R. (2009). Issledovanie vozmozhnostej primeneniya novyh tipov zdanij, ispol'zuyushchih prostranstvo nad zanyatymi territoriyami $\mathrm{v}$ gorodskoj zastrojke [Study into the possibility of using new types of buildings that use space above the occupied areas in urban development]. Bulletin of the Moscow State University of Civil Engineering, 3, 66-70.

Kuzmich, S.I., Fedina, T.O. (2008). Transportnye problemy sovremennyh gorodov i modelirovanie zagruzki ulichno-dorozhnoj seti [Transport problems of modern cities, and modeling of the road network loading]. Bulletin of the Tula State University. Technical Sciences, 3, 159-166.

Lipadat, V. (2020). Issledovanie vozmozhnostej primeneniya zdanij-mostov s obshchestvennoj funkciej dlya renovacii territorii r. YAuzy [Study of the possibilities of using bridge-type buildings with a public function for the renovation of the Yauza River territory]. Master's thesis.

Vladimirov, S.N. (2014). Transportnye zatory v usloviyah megapolisa [Transport congestions in a megalopolis]. Bulletin of the Moscow State Technical University "MAMI", 1(19), 77-84.

Zabalueva, T.R., Zakharov, A.A., Maslova, T.A. (2014). Building-bridge. Patent of Russia No. 2513231.2014. Bul. No. 11.

Zakharov, A.V., Fleishman, S.L. (2016). Sovershenstvovanie ulichno-dorozhnyh setej posredstvom zdanij-mostov [Improvement of street and road networks employing bridge-type buildings]. Industrial and Civil Construction, 6, 52-56. 